\title{
Role of insulin hormone in modulation of inflammatory phenomena
}

\author{
Papel do hormônio insulina na modulação dos fenômenos inflamatórios
}

\author{
Antonio Di Petta*
}

\begin{abstract}
Evidence demonstrates the involvement of hormones in the development of inflammatory response. Inflammation evokes marked structural alterations of microvasculature, besides migration of leukocytes from microcirculation to the site of lesion. These alterations are caused primarily by release or activation of endogenous mediators, in which hormones play an integral role in this regulatory system. Binding sites for many hormones may be characterized by vascular structures and hematogenous cells involved with the inflammatory response. Quantitative alterations of inflammatory events involving the decrease in microvascular response to inflammatory mediators, deficiency in the leukocyte-endothelium interaction, reduction of cell concentration in the inflammatory exudate, and failure of the phagocyte function of mononuclear cells were observed in insulindeficient states. Therefore, inflammation is not merely a local response, but rather a process controlled by hormones in which insulin plays an essential role in modulation of these phenomena, and assures tissue repair and remodeling within the limits of normality.
\end{abstract}

Keywords: Insulin; Inflammation; Hormones; Chemotaxis, leukocyte; Microcirculation

\section{RESUMO}

Evidências demonstram 0 envolvimento dos hormônios no desenvolvimento da resposta inflamatória. A inflamação evoca alterações estruturais marcantes da microvasculatura, além da migração dos leucócitos da microcirculação para o foco da lesão. Essas alterações são ocasionadas principalmente pela liberação ou ativação de mediadores endógenos, na qual os hormônios participam integralmente desse sistema regulador. Sítios de ligação para muitos hormônios podem ser caracterizados em estruturas vasculares e células hematógenas envolvidas com a resposta inflamatória. Alterações quantitativas dos eventos inflamatórios envolvendo a diminuição da resposta microvascular aos mediadores inflamatórios, deficiência entre a interação leucócito-endotélio, redução da concentração celular no exudato inflamatório e falha na função fagocitária dos mononucleares foram observadas em estados insulino-deficientes. Portanto, a inflamação não é meramente uma resposta local, mas um processo controlado por hormônios, no qual a insulina desempenha um papel essencial modulando esses fenômenos, e assegurando uma reparação e um remodelamento tecidual dentro dos limites da normalidade.

Descritores: Insulina; Inflamação; Hormônios; Quimiotaxia de leucócito; Microcirculação

\section{INTRODUCTION}

Animal kingdom organisms, particularly vertebrates, are involved in a constant challenge in which external aggressors, such as trauma and infections, should be neutralized. However, in order to effectively respond to the challenge imposed, the organism activates a series of strictly conditioned events, characteristic of the inflammatory response, including structural and functional alterations of vessels, migration of hematogenous cells to the damaged area, phagocytosis, and local pain. Additionally, this reaction may be accentuated by means of recruitment of immune system components $^{(1)}$.

Due to the effect of manifestations evoked by the host organism in response to the pathogen stimulus, up until the end of the $18^{\text {th }}$ century, inflammation was considered a disease. Nevertheless, in 1794, Hunter described it as a non-specific intentional and beneficial response evoked by all types of lesion. In classic studies conducted by Miles and Niven, pyogenic bacteria were utilized as noxious stimulus, demonstrating convincingly the defensive aspect of the inflammatory response. In these experiments, recognized components of the initial phases of the inflammatory response were blocked by systemic shock, local ischemia, or administration of anticomplement substances. The results demonstrated that

\footnotetext{
"Graduate program (PhD) in Thoracic and Cardiovascular Surgery, Faculdade de Medicina, Universidade de São Paulo - USP, Sao Paulo (SP), Brazil.

Corresponding author: Antonio Di Petta - Institute of Heart (InCor), LIM-11 - University of São Paulo Medical School - Av. Dr. Enéas de Carvalho Aguiar, 44 - $05403-000$ São Paulo - SP - Brazil - Tel/ Fax: 551130617178 -E-mail: antoniodipetta@usp.br

Received on: Nov 29, 2009 - Accepted on: Aug 03, 2011
} 
the effect of host resistance in developing an adequate response to the bacterial lesion resulted in a maximum lesion, substantially greater and more severe than the lesions developed in animals, in which the initial stages of inflammation were not blocked. These experiments contributed to understand that an adequate initial response is essential to prevent or limit the intensity of a future lesion ${ }^{(2-5)}$.

Chemical mediators and tissue, plasma, and neurogenic factors are fundamental for the development of inflammatory process. Nevertheless, evidence indicates, in a relevant manner, the influence of hormones in modulation of the inflammatory response ${ }^{(1,6)}$.

Hormones play a primordial role on regulatory mechanisms of the inflammatory process, as they are responsible for the fine tuning which is altered according to severity of the lesion. In a series of studies conducted in the beginning of the 1970s, by Garcia Leme et al., it was clearly demonstrated that insulin and glucocorticoids exert a direct regulatory effect on structural reactions of the inflammed area. Additionally, hormones influence significant cellular function in the development of the inflammatory response. Evidence indicates that decompensated diabetic patients are more susceptible to infections, which are manifested with greater severity and are more difficult to eradicate ${ }^{(1,7)}$. Adequate insulin concentrations seem to be essential for the manifestation of functional alterations of endothelial cells and leukocytes in the presence of the inflammatory process. The present article aimed to demonstrate the interaction between the insulin hormone and modulation of inflammatory response.

\section{INFLAMMATORY PROCESS}

The inflammatory process is characterized by the response of vascularized connective tissue to damaging endogenous or exogenous stimuli ${ }^{(8)}$. These harmful stimuli of a chemical, physical, or biological nature trigger a series of functional and morphological changes in cells, tissues, and blood and lymph vessels, circumscribing the damaged $\operatorname{area}^{(6)}$.

The inflammatory response is fundamental for destroying, diluting, or eliminating the aggressor agent, evolving to scarring and reconstitution of the damaged tissue. The inflammatory process displays two distinct patterns of manifestation: acute inflammation, characterized by the immediate and early response to a harmful agent; and chronic inflammation, characterized by prolonged duration, in which active inflammation, tissue destruction, and attempts at repair occur simultaneously ${ }^{(8)}$.

The manifestation of the acute inflammatory response involves alterations in vascular caliber, promoting increased blood flow, structural alterations in microvasculature, leading to increased vascular patency, followed by formation of inflammatory exudate and migration of leukocytes from microcirculation to the site of the lesion ${ }^{(8)}$.

It initiates with a variable and transient vasoconstriction followed by vasodilatation involving first the adjacent microvessels, and second, the opening of new capillary beds in the damaged area, resulting in increased local blood flow. Vascular patency observed during the course of the inflammatory response results from the opening of interendothelial junctions, present in postcapillary venules, and from protein leakage into perivascular tissue ${ }^{(6,8)}$. Since the velocity of blood flow drops, due to vasodilatation, erythrocyte groupings form that exhibit greater masses that those of the leukocytes, thus dislocating them to the periphery of the vessels ${ }^{(9)}$. The leukocytes start to adhere momentarily to the endothelium, initially transitorily (rolling), and then, they adhere firmly (firm adherence). After firm adherence, leukocytes emit pseudopods through the interendothelial junctions, in order to reach the extravascular region ${ }^{(10)}$.

Increase in adhesion strength depends on structural alterations of the molecules responsible for interaction of the leukocyte surface with the endothelial cell surface. These molecules are called adhesion molecules and, in this particular case, they belong to distinct structures called selectins, integrins, and molecules of the superfamily of immunoglobulins. Selectins include P-selectin, present in the endothelium and platelets; E-selectin, confined to the endothelium; and L-selectin, expressed by many types of leukocytes. Selectin ligands are oligosaccharides associated with glucoproteins present in the membranes of adjacent cells. Selectins and their ligands are the elements responsible for leukocyte rolling over the endothelium ${ }^{(11)}$. Molecules of the immunoglobulin superfamily include molecules ICAM-1 (intercellular adhesion molecule-1), ICAM-2, VCAM-1 (vascular cell adhesion molecule-1), and PECAM-1 (platelet endothelial cell adhesion molecule-1). Their ligands include molecules from the b2-integrin family (CD11a/CD18, CD11b/CD18) ${ }^{(12)}$.

Numerous mediators of the inflammatory process, such as histamine, thrombin, platelet activation factor (PAF), and cytokines, such as tumor necrosis factoralpha (TNF- $\alpha$ ) and interleukin-1 beta (IL-1 $\beta$ ), for example, are the elements responsible for expression of these adhesion molecules ${ }^{(13)}$.

\section{MODULATORY ACTION OF THE INSULIN HORMONE ON INFLAMMATORY RESPONSE}

Adequate concentrations of insulin seem to be essential for the manifestation of functional alterations of 
endothelial cells and leukocytes in the presence of the inflammatory process. Studies conducted in vitro with neutrophils from diabetic patients documented defects in leukocyte function, such as reduced adhesion capacity, phagocytosis, bactericidal activity, and production of reactive oxygen species ${ }^{(14)}$. In a systematic study of leukocyte function in an experimental model of pleurisy, it was noted that the neutrophil cellular infiltrate was reduced in rats made diabeticbyaloxaneinjection. Failure in cell recruitment is associated with the presence of a protein $(>12 \mathrm{kDa}$ ) present in plasma with an inhibitory effect on the chemotaxis of neutrophils ${ }^{(15)}$. Utilizing intravital microscopy techniques, it was observed that an analogous protein is associated with the inhibition of leukocyte-endothelium interactions ${ }^{(16)}$. The relatively prolonged treatment of animals with insulin (12 days) resulted in gradual recovery of chemotaxis evaluated in vivo (pleurisy, intravital microscopy) and in vitro (Boyden chamber). Nevertheless, acute treatments (3 days) are not effective ${ }^{(15,17)}$. Associated with chemotaxis inhibition is a protein altered by glycation reaction ${ }^{(18)}$, with suppressive activity on the expression of adhesion molecule ICAM-1 in endothelial cells of postcapillary venules $^{(19)}$. Treatment of animals with insulin restores the expression of ICAM-1 in the microvascular endothelium to normal values ${ }^{(19)}$. By means of an intravital microscopic technique, it was noted that the leukocytes in contact with the venular endothelium (rolling behavior) are markedly reduced in rats made diabetic by aloxane injection, at 10,30, or 180 days before. Under the influence of an inflammatory stimulus, leukocytes migrate to the perivascular tissue of control animals and this event is accompanied by a reduction in the number of cells that roll over the endothelium. In diabetic animals, the number of leukocytes that roll over the endothelium does not change, but few cells migrate to the adjacent connective tissue. These observations do not, however, reflect white blood cell count alterations. Relatively prolonged treatment (12 days) of diabetic animals with insulin corrects the defect in leukocyte-endothelium interaction and, consequently, the inflammatory cellular infiltrate ${ }^{(16,17,19)}$.

In a model of IgE-mediated hypersensitivity in rats, a reduction in the number of cells present in the broncoalveolar lavage was noted in those animals made diabetic. Treatment of these animals with a single dose of insulin (NPH, 4 IU) immediately before the antigenic challenge completely corrected this response ${ }^{(20)}$. On the other hand, a 15-hour fast normalizes blood glucose, but it does not modify the characteristics of the bronchoalveolar lavage of diabetic rats sensitized and bronco-challenged, indicating that the simple correction of blood glucose is not sufficient to restore the IgE-mediated hypersensitivity response ${ }^{(20)}$.
Additionally, the serum concentration of corticosterone, the prevalent glucocorticoid in rats, is not different in control and diabetic rats because of aloxane, which reinforces the direct intervention of insulin in controlling the lesion ${ }^{(21)}$. The response capacity of the host to pathogen agents seems to be associated with the integration of functions of endogenous glucocorticoids and insulin. When there is a failure in this regulatory activity, control and neutralization of the harmful stimulus are compromised, and a reaction, which is initially transitory, tends to be sustained, and often becomes deleterious ${ }^{(1,6)}$.

It was further noted that the reduction of the inflammatory cellular infiltrate in diabetes mellitus is associated with the reduced expression of ICAM-1, confined to the vascular endothelium and alveolar epithelium, reestablishing normal values after treatment of the animals with insulin ${ }^{(22)}$. In a recent study, using a model of IgE-mediated hypersensitivity in rats, it was noted that segments of trunk bronchi and intraparenchymal bronchi isolated from diabetic animals displayed reduced contractile response to ovalbumin (in vitro challenge) resulting from less mast cell degranulation. Treatment of diabetic animals with a single dose of insulin or with the in vitro addition of the hormone corrects these alterations ${ }^{(23)}$.

Studies conducted in a model of acute pulmonary inflammation induced by Escherichia coli lipopolysaccharides (LPS) consistently indicate the participation of insulin in the regulation of various aspects of this response. It was noted that rats made diabetic by aloxane injection exhibit reduced generation of superoxide ions by leukocytes present in the bronchoalveolar lavage ${ }^{(24)}$; reduction in the uptake of arachidonic acid and release of prostaglandin $\mathrm{E}_{2}{ }_{2}^{(7)}$; reduction in the production of proinflammatory cytokines (TNF- $\alpha$, IL-1 $\beta$ ) and anti-inflammatory cytokines (IL$10)^{(21)}$, events associated with the reduction of the pulmonary inflammatory cellular infiltrate ${ }^{(7)}$. Treatment of the animals with insulin completely restores these abnormalities.

These studies contributed towards understanding why decompensated diabetic patients are more susceptible to infections that manifest with greater severity and are more difficult to eradicate ${ }^{(1,7)}$ and why a few years after the introduction of insulin into therapeutics, it was noted that mortality due to infectious processes had diminished in diabetic patients.

The inflammatory response is not merely a local expression event, but rather a complex and extensive reaction of the organism as a whole. There is much evidence for the regulatory role of hormonal systems in the inflammatory process. Bonding sites for many hormones may be characterized in vascular structures 
and hematogenous cells involved with the inflammatory response; endocrine dysfunctions affect fundamental stages in response to damage; plasma concentrations of various hormones are altered over the duration of the inflammatory process; hormone actions may represent relevant aspects in the body's defense against infections ${ }^{(6)}$.

\section{FINAL CONSIDERATIONS}

Finally, inflammation is not merely a local response, but rather a process controlled by hormones, in which the insulin hormone plays a fundamental role in modulating the development of the inflammatory response, assuring tissue repair and remodeling within limits of normality. Therefore, an adequate initial response is essential to prevent or limit severity of a future lesion.

\section{REFERENCES}

1. Garcia-Leme J, Farsky SP. Hormonal control of inflammatory responses. Mediat Inflamm. 1993;2(3):181-98.

2. Miles AA, Niven SF. The enhancement of infection during shock produced by bacterial toxins and other agents. Br J Exp Pathol. 1950;31:73-80.

3. Miles AA. Nonspecific defense reactions in bacterial infections. Ann NY Acad Sci. 1956;66:356-61.

4. Miles AA, Miles EM, Burke JF. The value and duration of defense reactions of the skin to the primary lodgment of bacteria. Br J Exp Patol. 1957;38:798396.

5. Leak LV, Burk JF. Early events of tissue injury and the role of the lymphatic system in early inflammation. In: Zweifach BW, Grant L, McCluskey RT, editors. The inflammatory process. 2nd ed. New York: Academic Press; 1974. p. 163-265.

6. Garcia-Leme J. Hormones and inflammation. Boca Raton: CRC Press; 1989.

7. Alba-Loureiro TC, Munhoz CD, Martins JO, Cerchiaro CA, Scavone C, Curi $\mathrm{R}$, et al. Neutrophil function and metabolism in individuals with diabetes mellitus. Braz J Med Biol Res. 2007;40(8):1037-44.

8. Collins T. Inflamação aguda e crônica. In: Cotran RS, Kumar V, Collins T. Patologia estrutural e funcional. 6a ed. Rio de Janeiro: Guanabara Koogan; 2000. p. 44-78.
9. Wilhelm DL. Inflammation and healing. In: Pathology. 7a ed. St. Louis: WAD Anderson \& JM Kissane; 1977. p. 25-89.

10. Atherton A, Born GVR. Quantitative investigations of the adhesiveness of circulating polymorphonuclear leukocytes to blood vessel walls. J Physiol. 1972;222(2):447-74.

11. Rosen SD. Ligands for L-selectin: homing, inflammation, and beyond. Annu Rev Immunol. 2004;22:129-56.

12. Mayadas TN, Cullere X. Neutrophil $\beta 2$-integrins: moderators of life or death decisions. Trends Immunol. 2005;26(7):388-95.

13. Pober JS, Cotran RS. Cytokines and endothelial cell biology. Physiol Rev. 1990;70(2):427-51.

14. MarhofferW, Stein M, MaeserE, Federlin K. Impairment of polymorphonuclear leukocyte function and metabolic control of diabetes. Diabetes Care. 1992;15(2):256-60.

15. Pereira MA, Sannomiya P, Garcia-Leme J. Inhibition of leukocyte chemotaxis by factor in alloxan-induced diabetic rat plasma. Diabetes. 1987;36(11):1307-14.

16. Fortes ZB, Farsky SP, Oliveira MA, Garcia-Leme J. Direct vital microscopic study of defective leukocyte-endothelial interactions in diabetes mellitus. Diabetes. 1991;40(10):1267-73

17. Sannomiya P, Pereira MAA, Garcia-Leme J. Inhibition of leukocyte chemotaxis by serum factor in diabetes mellitus: selective depression of cell response mediated by complement-derived chemoattractants. Agents Actions. 1990;30(3-4):369-76.

18. Sannomiya P, Oliveira MA, Fortes ZB. Aminoguanidine and the prevention of leukocyte dysfunction in diabetes mellitus: a direct vital microscopic study. Br J Pharmacol. 1997;122(5):894-8.

19. Anjos-Valota EA, Martins JO, Oliveira MA, Casalori DA, Brito LRG, Tostes $\mathrm{RC}$, et al. Inhibition of tumor necrosis factor- $\alpha$-induced intercellular adhesion molecule-1 expression in diabetic rats: role of insulin. Inflamm Res. 2006;55(1):16-22.

20. Vianna ESO, Garcia-Leme J. Allergen-induced airway inflammation in rats. Role of insulin. Am J Respir Crit Care Med. 1995;151 (3 Pt 1):809-14.

21. de Oliveira Martins J, Meyer-Pflug AR, Alba-Loureiro TC, Melbostad H, Costa da Cruz JWM, Coimbra R, et al. Modulation of lipopolysaccharide-induced acute lung inflammation: role of insulin. Shock. 2006;25(3):260-6.

22. Sannomiya P, Manzolli S, Alves VAF, Martins MA, Vianna EO. Insulin modulates the expression of ICAM-1 (CD54) in allergen-induced airway inflammation. Med Inflamm. 1999;8(Suppl1):S92.

23. Cavalher-Machado SC, de Lima WT, Damazo AS, de Frias Carvalho V, Martins MA, Silva PM, et al. Down-regulation of mast cell activation and airway reactivity in diabetic rats: role of insulin. Eur Respir J. 2004;24(4):552-8.

24. Boichot E, Sannomiya P, Escofier N, Germain N, Fortes ZB, Lagente V. Endotoxin-induced acute lung injury in rats. Role of insulin. Pulm Pharmacol Therap. 1999;12(5):285-90. 